\title{
Somatostatin and the intestinal transport of glucose and other nutrients in the anaesthetised rat
}

\author{
C DAUMERIE AND J C HENQUIN \\ From the Unité de Diabète et Croissance, University of Louvain School of Medicine, Brussels, Belgium
}

SUMmaRY The effects of somatostatin on oral glucose tolerance and on intestinal absorption of glucose and other nutrients have been studied in anaesthetised rats. Intravenous somatostatin (0.1$0.6 \mathrm{nmol} / \mathrm{min}$ ) increased the rate of gastric emptying. After intraduodenal administration of glucose, the rise in peripheral plasma levels of the sugar was delayed, but finally exaggerated by somatostatin, which inhibited the insulin response. Absorption was evaluated by measuring the disappearance of radioactive nutrients from the lumen of a 'tied duodenojejunal loop'. At a luminal concentration of $4 \mathrm{mmol} / \mathrm{l}$ of 3-0-methylglucose, neither disappearance of the sugar from the lumen nor its appearance in plasma was affected by somatostatin. Passive transport of 3-0-methylglucose (100 mmol/l) was not significantly modified by somatostatin, although the appearance of the labelled tracer in plasma was delayed. Somatostatin had no significant effect on absorption of galactose $(4 \mathrm{mmol} / \mathrm{l})$, sucrose $(40 \mathrm{mmol} / \mathrm{l})$, leucine $(4 \mathrm{mmol} / \mathrm{l})$ or palmitate $(0.1$ and $0.4 \mathrm{mmol} / \mathrm{l})$. These results show that somatostatin delays appearance of ingested sugars in peripheral plasma without direct effect on the absorption sites; this delay may result from changes in intestinal motility, enzyme secretion and splanchnic blood flow.

Studies by Gerich et al. have shown that intravenous administration of somatostatin to diabetic subjects improves their glucose tolerance after meals and oral glucose loads. ${ }^{1}$ This phenomenon was attributed to inhibition of glucagon release by somatostatin. Wahren and Felig, however, challenged this interpretation and suggested that somatostatin delays intestinal absorption of carbohydrates. ${ }^{2}$ Their proposal was based on the observation that in these diabetic subjects exogenous somatostatin markedly slowed the appearance of ingested xylose in peripheral plasma.

The hypothesis has been advanced that somatostatin, released during meals, could be a physiological regulator of the rate at which ingested nutrients enter the circulation. ${ }^{3}$ Several studies in humans and animals have been carried out to substantiate this proposal. ${ }^{4-13}$ Conflicting results have appeared and their interpretation is not always straightforward. Thus, it is possible that somatostatin has no direct effect on the intestinal absorption itself, but slows the entry of nutrients in the blood by affecting gastric emptying, ${ }^{14}$ intestinal motility, ${ }^{15-17}$ gallbladder contraction, ${ }^{18}$ digestive enzyme release, ${ }^{18-21}$ or splanchnic blood flow. ${ }^{22} 23$

Received for publication 18 November 1981
In the present study, carried out in anaesthetised rats, we have investigated the influence of exogenous somatostatin on oral glucose tolerance and evaluated its possible effects on intestinal absorption of glucose and other nutrients.

\section{Methods}

ANIMALS

Experiments were performed in female Wistar rats $(200-230 \mathrm{~g})$ fasted for 18 hours. They were anaesthetised by an intraperitoneal injection of pentobarbital $(30 \mathrm{mg} / \mathrm{kg})$ followed, when required, by an additional intramuscular injection $(6 \mathrm{mg} / \mathrm{kg})$. Body temperature was maintained at $37^{\circ} \mathrm{C}$ with a heating pad.

One jugular vein was cannulated for infusion of somatostatin, dissolved in physiological saline supplemented with $2.5 \mathrm{mg}$ bovine serum albumin per $\mathrm{ml}$. The doses of somatostatin were: a bolus of $1 \mathrm{nmol}$ in $30 \mathrm{sec}$ onds, followed by an infusion of $0.1 \mathrm{nmol} / \mathrm{min}$ or a bolus of $6 \mathrm{nmol}$ followed by an infusion of $0.6 \mathrm{nmol} / \mathrm{min}$. Saline alone was similarly infused in control animals.

MEASUREMENT OF GASTRIC EMPTYING A method slightly modified from the description of Poulakos and Kent ${ }^{24}$ was used. The abdominal cavity was opened and a loose ligature was placed around the 
pylorus. Two millilitres of physiological saline, at $37^{\circ} \mathrm{C}$, containing $5 \mathrm{mg} / \mathrm{ml}$ polyvinylpyrrolidone (PVP) and a trace amount of ${ }^{125} \mathrm{I}-\mathrm{PVP}(30 \mathrm{nCi} / \mathrm{ml})$, were introduced into the stomach through an oral catheter pushed just below the cardia. Thirty minutes later, the ligature around the pylorus was secured, another ligature was tied around the cardia, and the stomach was removed. After opening and washing, its content in ${ }^{125}$ I-PVP was counted. Gastric emptying is defined as the percentage of ${ }^{125}$ I-PVP that has left the stomach after 30 minutes. The intravenous perfusion of somatostatin was started 10 minutes before introduction of the gastric catheter.

\section{INTRADUODENAL GLUCOSE LOAD}

A small catheter was introduced into the duodenum through the anterior wall of the stomach and secured in place by a ligature around the pylorus. Glucose (5.5 $\mathrm{mmol} / \mathrm{kg}$ body weight) was dissolved in $2 \mathrm{ml}$ of water at $37^{\circ} \mathrm{C}$. Somatostatin infusion started 20 minutes before and finished 45 minutes after glucose administration. Blood was collected from the tail vein for measurement of plasma glucose by the glucose oxidase method (Beckman Instruments) and of immunoreactive insulin by a double antibody assay with rat insulin as standard.

\section{MEASUREMENT OF INTESTINAL ABSORPTION OF GLUCOSE OR OTHER NUTRIENTS \\ Technique and solutions}

Absorption was studied in a tied duodenojejunal loop of anaesthetised rats. The preparation was only slightly modified from the description by Salem et al. ${ }^{25}$ An inflow catheter was introduced into the duodenum, through the anterior wall of the stomach, and secured in place with a ligature around the pylorus. An outflow catheter was placed in the jejunum, $20-25 \mathrm{~cm}$ below. The bile duct was tied at the entrance in the duodenum. The loop was first washed clean with normal saline at $37^{\circ} \mathrm{C}$, infused with a peristaltic pump $(0.4 \mathrm{ml} / \mathrm{min})$, and then emptied with air.

After the outflow catheter was clamped, $2 \mathrm{ml}$ of a salt-balanced medium (in $\mathrm{mmol} / \mathrm{l}$ ) : $\mathrm{NaCl}, 130 ; \mathrm{KCl}, 6$; $\mathrm{CaCl}_{2}, 1 ; \mathrm{MgCl}_{2}, 1 ; \mathrm{NaHCO}_{3}, 10$; gassed with $94 \% \mathrm{O}_{2}-$ $6 \% \mathrm{CO}_{2}, \mathrm{pH} \mathrm{6.9}$, were introduced into the loop. The medium was supplemented with various concentrations of glucose or 3-0-methylglucose, galactose, sucrose, leucine, or palmitate, and with a trace amount of the same substance labelled with ${ }^{3} \mathrm{H}$ or ${ }^{14} \mathrm{C}$. Details of the specific activities used are given in the legends to the Figures and Tables. Palmitate was emulsified with bovine serum albumin or dissolved with taurocholic acid $(10 \mathrm{mmol} / \mathrm{l})$. When the concentration of glucose was $100 \mathrm{mmol} / \mathrm{l}$, the concentration of $\mathrm{NaCl}$ was reduced to $80 \mathrm{mmol} / \mathrm{l}$.

After 20 minutes, the loop was opened and washed with saline. The effluent radioactivity was collected in several fractions to which $10 \mathrm{ml}$ Aqualuma (Lumac SA, Meise, Belgium) were added for determination of the radioactive content. Correction of quenching was applied by the external standardisation method. The intestinal segment was then removed and dried before weighing. Net absorption was calculated from the difference between the infused and the recovered radioactivity. Taking into account the specific activity of the substance, absorption is expressed as $\mu \mathrm{mol}$ of substance absorbed per $\mathrm{g}$ of dry intestine over 20 minutes.

\section{Experiment protocols}

One period of absorption Glucose or 3-0-methylglucose was introduced into the loop for 20 minutes and blood was taken from the tail vein to measure appearance of the labelled sugar in the circulation (100 $\mu \mathrm{l}$ plasma into $10 \mathrm{ml}$ Aqualuma). Somatostatin infusion started 10 minutes before introduction of the sugar and lasted until the end of the absorption period. In these experiments, the radioactivity remaining in the dried intestinal segment was determined after digestion of the tissue ${ }^{26}$.

Two successive periods of absorption The absorption of the same nutrient was studied twice in the same animal during periods of 20 minutes separated by a washing period of 30 minutes. Control animals were infused with saline throughout the experiment, whereas, in test animals, somatostatin was substituted for saline 10 minutes before the onset of the second period.

\section{CHEMICALS}

Cyclic somatostatin was obtained from Bachem Inc. (Marina Del Rey, CA, USA). 3-0-methylglucose and taurocholic acid were from Sigma Chemical Co (St Louis, Mo, USA), polyvinylpyrrolidone from Aldrich Europe (Beerse, Belgium), and all other reagents from Merck A G (Darmstadt, Germany). Radiochemicals: D- $\left[\mathrm{U}-{ }^{14} \mathrm{C}\right]$ glucose, 3-0-methyl-D-[U- $\left.{ }^{14} \mathrm{C}\right]$ glucose, D$\left[5-{ }^{3} \mathrm{H}\right]$ glucose, $\mathrm{D}-\left[1-{ }^{3} \mathrm{H}\right]$ galactose, $\left[6,6{ }^{\prime}{ }^{3} \mathrm{H}\right]$ sucrose, L- $\left[4,5-{ }^{3} \mathrm{H}\right]$ leucine, $\left[1-{ }^{14} \mathrm{C}\right]$ palmitic acid and ${ }^{125} \mathrm{I}$-polyvinylpyrrolidone were all purchased from the Radiochemical Centre (Amersham, UK).

\section{PRESENTATION OF RESULTS}

Results are presented as means \pm SEM and the statistical significance of differences between experimental groups was assessed using Student's $t$ test for unpaired data, except where explicitly stated.

\section{Results}

EFFECTS OF SOMATOSTATIN ON GASTRIC EMPTYING

In control rats, gastric emptying after $\mathbf{3 0}$ minutes was 


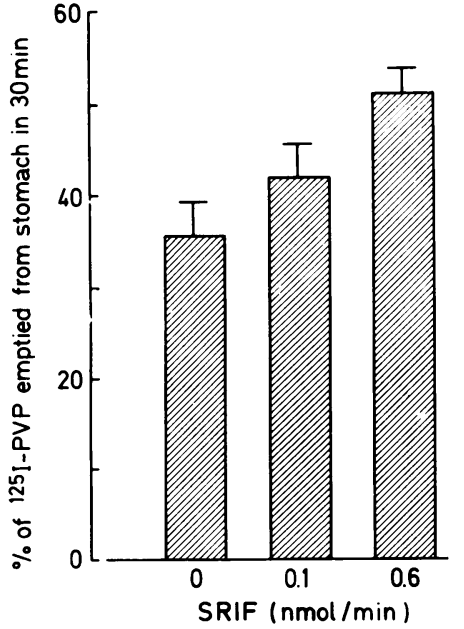

Fig. 1 Effect of somatostatin (SRIF) on gastric emptying in anaesthetised rats. Values are means $\pm S E M$ for six animals.

$37 \cdot 7 \pm 3 \cdot 5 \%$. As shown by Fig. 1, intravenous somatostatin accelerated $(P<0.005)$ the rate of emptying during perfusion of the hormone at the dose of 0.6 $\mathrm{nmol} / \mathrm{min}$.

\section{EFFECTS OF SOMATOSTATIN ON GLUCOSE TOLERANCE}

In control rats, introduction of glucose directly into the duodenum was followed by a rapid and marked increase in plasma glucose levels (Fig. 2). They remained fairly stable from 15 to 45 minutes and then declined progressively. Simultaneously, the insulin levels increased promptly to a peak at 15 minutes and decreased regularly later on.

Twenty minutes after the start of somatostatin infusion, plasma insulin levels had decreased from $1.6 \pm$ $0.2 \mathrm{ng} / \mathrm{ml}$ to $0.9 \pm 0.1 \mathrm{ng} / \mathrm{ml}(\mathrm{P}<0.01$ by paired $t$ test), but plasma glucose levels had not changed. After glucose administration, plasma glucose levels rose slightly less rapidly than in control animals $(P<0.025$ at 15 minutes) and continued to increase regularly until 60 minutes. Thereafter they diminished but remained significantly higher than in rats which did not receive somatostatin. Somatostatin blunted the rise in plasma insulin levels and a rebound was observed when perfusion of the hormone was stopped (Fig. 2).

\section{EFFECTS OF SOMATOSTATIN ON APPEARANCE OF INGESTED SUGARS IN PERIPHERAL PLASMA}

After introduction of a low concentration $(4 \mathrm{mmol} / \mathrm{l})$ of 3-0-methylglucose labelled with ${ }^{14} \mathrm{C}$ in the intestinal loop, ${ }^{14} \mathrm{C}$ activity was rapidly detectable in peripheral plasma (Fig. 3). This kinetics was not modified by somatostatin, which was also without effect on the disappearance of the labelled sugar from the intestinal lumen (Fig. 3, right panel).

When the concentration of 3-0-methylglucose was higher $(100 \mathrm{mmol} / \mathrm{l}),{ }^{14} \mathrm{C}$ activity in plasma rose steadily until the intestinal loop was opened and washed at 20 minutes (Fig. 3). Somatostatin slowed down the appearance of the labelled sugar in plasma; the maximum was reached only at 30 minutes, after the loop had been opened and the perfusion of the hormone stopped. This effect of somatostatin was not accompanied by any significant difference in the disappearance of the sugar from the lumen. There was no difference between the mean dry weight of the intestinal loop in each group. At the end of the experiment, $0.7 \pm 0.1 \%$ of the radioactive 3-0-methylglucose introduced into the lumen of control loops was recovered from the intestinal wall.
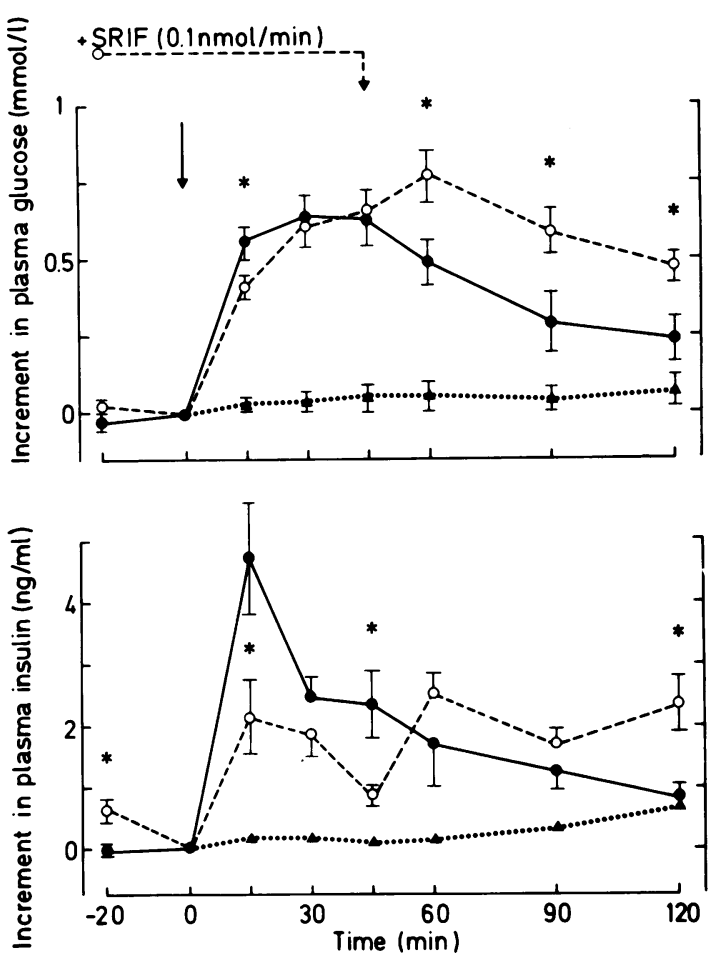

Fig. 2 Effect of somatostatin (SRIF) on plasma glucose and insulin levels after intraduodenal administration of glucose to anaesthetised rats. Results are expressed as the increment above values at 0 minute, when glucose (5.5 $\mathrm{mmol} / \mathrm{kg}$ body weight) (O and O) or saline ( $\Delta$ ) was administered. In one series (O) SRIF was infused from -20 minutes to 45 minutes. Values are means \pm SEM for nine animals, except for controls with intraduodenal saline, where $n=7$. Asterisks denote significant effects of SRIF $(P<0.025$ or more). 
This percentage was not different $(0 \cdot 8 \pm 0.1 \%)$ after infusion of somatostatin.

Essentially similar results were obtained when ${ }^{14} \mathrm{C}$ glucose was introduced in the duodenum (not shown), but the possible contribution of glucose metabolites to the plasma ${ }^{14} \mathrm{C}$-radioactivity was not evaluated.

\section{EFFECT OF SOMATOSTATIN ON ABSORPTION} OF VARIOUS NUTRIENTS

The Table details the results of experiments in which the absorption of various nutrients was studied during two successive periods in each animal. Glucose absorption was measured at three luminal concentrations of the sugar: $4 \mathrm{mmol} / 1$, to evaluate the active transport (inhibited by $54 \pm 3 \%, n=4$, in the presence of 0.1 $\mathrm{mmol} / \mathrm{l}$ phlorizin) and $100-500 \mathrm{mmol} / \mathrm{l}$ to evaluate the passive transport of the sugar. At all concentrations,

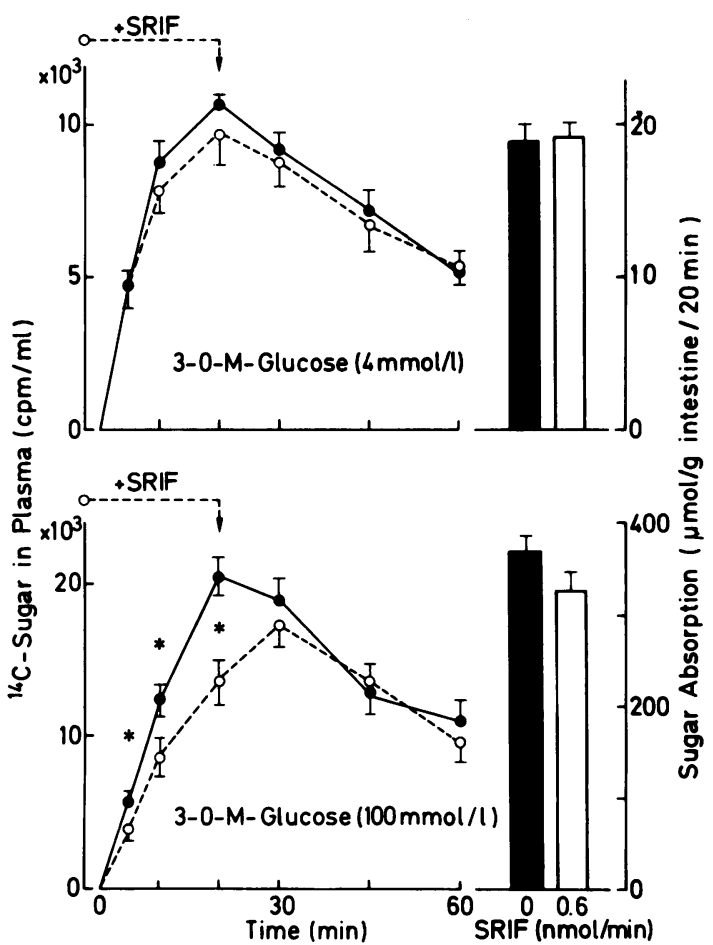

Fig. 3 Effect of somatostatin (SRIF) on intestinal absorption of 3-0-methylglucose in anaesthetised rats. The sugar was present in the intestinal loop between 0 and 20 minutes, at the indicated concentration, together with 0.5 $\mu \mathrm{Ci}$ (upper panel) or $1 \mu \mathrm{Ci}$ (lower panel) of $\left[{ }^{4} \mathrm{C}\right]$-tracer. The left panels show the appearance of the radioactivity in peripheral plasma; the right panels show the disappearance of the radioactivity from the intestinal lumen. Control animals (1) and black columns) received saline infusion throughout, whereas test animals (O and open columns) received a SRIF infusion. Values are means $\pm S E M$ for six animals.
Table Effect of exogenous somatostatin on intestinal absorption of various substances

\begin{tabular}{|c|c|c|c|}
\hline \multirow{3}{*}{$\begin{array}{l}\text { Test } \\
\text { substance } \\
\text { (mmol/l) }\end{array}$} & \multicolumn{3}{|c|}{ Amount of substance absorbed } \\
\hline & \multirow{2}{*}{$\begin{array}{l}\text { Period I } \\
(\mu \mathrm{mol} / \mathrm{g} / 20 \mathrm{~min})\end{array}$} & \multicolumn{2}{|c|}{ Period II (\% of period I) } \\
\hline & & Controls & + Somatostatin \\
\hline $\begin{array}{l}\text { Glucose } 4 \\
\text { Glucose } 100 \\
\text { Glucose } 500 \\
\text { Galactose } 4 \\
\text { Sucrose } 40 \\
\text { Leucine } 4 \\
\text { Palmitate } 0.1 \\
\text { Palmitate } 0.4\end{array}$ & $\begin{array}{c}17 \pm 1 \\
209 \pm 15 \\
933 \pm 75 \\
20 \pm 1 \\
51 \pm 4 \\
16 \pm 1 \\
0.31 \pm 0.01 \\
1.41 \pm 0.05\end{array}$ & $\begin{aligned} 98 & \pm 1(6) \\
104 & \pm 11(6) \\
90 & \pm 8(5) \\
94 & \pm 4(3) \\
107 & \pm 7(6) \\
94 & \pm 2(3) \\
88 & \pm 5(4) \\
93 & \pm 4(6)\end{aligned}$ & $\begin{array}{r}95 \pm 1(6) \\
108 \pm 14(6) \\
89 \pm 6(8) \\
97 \pm 6(3) \\
94 \pm 4(6) \\
102 \pm 6(4) \\
93 \pm 5(4) \\
83 \pm 3(6)^{*}\end{array}$ \\
\hline
\end{tabular}

Absorption was measured during two successive periods of 20 minutes. In all animals, the first period was carried out during intravenous saline infusion, whereas the second period was carried out either during saline infusion (controls) or somatostatin infusion $(0.6 \mathrm{nmol} / \mathrm{min})$. For this second period, values are expressed as percentage of the absorption measured during the first period in the same animal. There was no significant difference between the mean dry weight of the loops in the different experimental series. Palmitate was emulsified with bovine serum albumin. Specific activities of the radioactive tracers were : D- $\left[5-{ }^{3} \mathrm{H}\right]$ glucose $(5,0.2$ and $0.04 \mu \mathrm{Ci} / \mathrm{mmol}), \mathrm{D}-\left[1-{ }^{3} \mathrm{H}\right]$ galactose (5 $\mu \mathrm{Ci} / \mathrm{mmol}),\left[6,6^{\prime}-{ }^{3} \mathrm{H}\right]$ sucrose $(0 \cdot 5 \mu \mathrm{Ci} / \mathrm{mmol}), \mathrm{L}-\left[4,5-^{-} \mathrm{H}\right]$ leucine $(5$ $\mu \mathrm{Ci} / \mathrm{mmol})$ and $\left[1{ }^{11} \mathrm{C}\right]$ palmitate $(125$ and $31 \mu \mathrm{Ci} / \mathrm{mmol})$. Values are means \pm SEM of a number of animals shown in parentheses.

* $P<0.005$ vs period I and $0.10<P<0.05$ vs controls in period II.

absorption of glucose was fairly stable during the two periods and was not significantly modified by the perfusion of somatostatin. Galactose transport was also unaffected by somatostatin (Table).

Absorption of the glucose and fructose moieties of sucrose was inhibited by $74 \pm 4 \%(n=4)$, when intraluminal sodium was replaced by Tris, a known inhibitor of the sucrase. ${ }^{27}$ By contrast, intravenous somatostatin (Table) or intraluminal somatostatin $(7.5 \mathrm{mmol} / 1$; not shown) had no effect. Leucine transport was not affected by somatostatin, which reduced slightly the absorption of palmitate when the intraluminal concentration of the fatty acid was $0.4 \mathrm{mmol} / \mathrm{l}$, but not when it was $0.1 \mathrm{mmol} / 1$. In other experiments, palmitate $(0 \cdot 1$ $\mathrm{mmol} / \mathrm{l})$ was dissolved with taurocholate; absorption was more important $(0.46 \pm 0.03 \mu \mathrm{mol} / \mathrm{g} / 20 \mathrm{~min})$ than after emulsification of the fatty acid with albumin (Table), but somatostatin, again, failed to affect this absorption $(0.44 \pm 0.02 \mu \mathrm{mol} / \mathrm{g} / 20 \mathrm{~min})$.

\section{Discussion}

The idea that somatostatin could modulate intestinal absorption of nutrients stems from the observation ${ }^{2}$ that its intravenous administration delays the appearance of ingested xylose in peripheral blood. We could confirm this original observation with an infusion of only $\mathbf{0 . 6}$ nmol somatostatin/min to normal subjects (unpublished data). Surprisingly, however, detailed studies of the effects of somatostatin on oral glucose tolerance in non-diabetic subjects are rather few. It was briefly re- 
ported recently ${ }^{28}$ that, after oral glucose, plasma levels of the sugar rose more slowly during somatostatin infusion. Marco et al. ${ }^{29}$ had shown earlier that, in nondiabetic gastrectomised patients, somatostatin causes a marked, but late impairment of the tolerance to oral glucose; during the initial 20 minutes, plasma glucose levels rose more slowly than during saline infusion. The same observation was made by Sakurai et al. ${ }^{4}$ after intraduodenal glucose load in dogs. Our findings in normal rats (Fig. 2) are thus superimposable on those made in man and dog. The major difference is that we had to use much higher doses of somatostatin, which may be considered pharmacological. These were required, however, to mimic reliably an effect observed with lower doses in the two other species.

The possibility that a delay of gastric emptying by somatostatin ${ }^{14}$ plays a role in its effect on oral glucose tolerance is unlikely for two reasons. First, exogenous somatostatin accelerates gastric emptying in rat (Fig. 1) and in $\operatorname{man} .{ }^{28}$ Second, the slower rise in peripheral plasma glucose is also observed when glucose is administered directly in the duodenum in rats (Fig. 2) and $\operatorname{dogs}^{4}$ as well as in gastrectomised patients. ${ }^{29}$

We found no evidence of a significant effect of exogenous somatostatin on carbohydrate absorption by a duodenojejunal loop in the anaesthetised rat. It is unlikely that mere technical problems inherent to this preparation account for the absence of effect. Thus, the validity of the method has already been assessed by others ${ }^{25}{ }^{30}$ and, in our hands, is supported by various arguments : absorption rates were well reproducible during successive periods; active glucose transport could be inhibited by phlorizin or sodium omission; sucrose absorption was reduced when the sucrase activity was inhibited by Tris; histological examination of the loop showed good preservation at the end of the experiments. This lack of effect of exogenous somatostatin on carbohydrate transport in the rat intestine is in agreement with the recent report of Wilson et al. ${ }^{13}$ but contrasts with the inhibitory effect described by Krejs et al. in man. ${ }^{12}$

By contrast, somatostatin delayed the appearance in peripheral plasma of the non-metabolised 3-0-methylglucose introduced in the duodenum. In rats receiving doses of somatostatin slightly higher (1-2 nmol $/ \mathrm{min})$ than those used here, others ${ }^{13}{ }^{31}$ have failed to disclose any delay in the appearance of gut-derived sugars in peripheral blood. It is unlikely that this discrepancy is due to their use of an intestinal segment distal to the duodenojejunal junction, instead of the duodenojejunum in our case. The use of lower intraluminal concentrations of the sugars $(0.02,10$, and $30 \mathrm{mmol} / \mathrm{l})$ is probably more important. Thus, such an effect of somatostatin was seen with the high $(100 \mathrm{mmol} / \mathrm{l})$, but not with the low intraluminal concentrations (4 $\mathrm{mmol} / \mathrm{l}$ ) of the sugars. These findings lend support to the hypothesis that the slower rise in plasma glucose after an oral load is really due to a delay in the appearance of ingested glucose in peripheral blood.

The infusion of somatostatin resulted in the expected decrease in plasma insulin levels and in a paradoxical delay in the rise of plasma glucose levels, without apparent difference in the disappearance of the sugar from the gut. In agreement with the conclusion arrived at by Wilson et al..$^{13}$ we believe that the reduction in splanchnic blood flow produced by somatostatin 2222 might well explain our findings. The fact that we found no evidence of any difference in the radioactivity retained in the intestinal wall is not necessarily irreconcilable with these findings. Thus, these measurements were made 40 minutes after the end of somatostatin infusion and the opening of the loop. It is possible that some accumulation took place at earlier times; its reliable measurement was precluded, however, by the requirement to wash completely the bulk of intraluminal radioactivity.

In conclusion, our results show that, in the rat, somatostatin delays appearance of ingested sugars in peripheral blood without reducing their intestinal absorption. The somatostatin control of the rate at which nutrients enter the circulation ${ }^{3}$ is thus apparently not due to a direct effect on transport systems but rather seems to involve indirect mechanisms: an alteration of intestinal motility, an interference with the digestion of complex substrates by inhibition of the exocrine pancreas and gall bladder function, ${ }^{18-21}$ and an effect beyond the absorption sites, on the splanchnic vessels. $^{32}{ }^{33}$

We thank Professor A E Lambert for continuous support, $F$ Mathot for her help with immunoassays, and $M$ Nenquin for typing the manuscript. C Daumerie is Aspirant and $\mathrm{JC}$ Henquin is 'Chercheur Qualifié' of the Fonds National de la Recherche Scientifique, Brussels. This study was supported in part by a grant-in-aid from Hoechst, Belgium.

\section{References}

1 Gerich JE, Lorenzi M, Hane S, Gustafson G, Guillemin R, Forsham PH. Evidence for a physiologic role of pancreatic glucagon in human glucose homeostasis: studies with somatostatin. Metabolism 1975; 24:175-82.

2 Wahren J, Felig P. Influence of somatostatin on carbohydrate disposal and absorption in diabetes mellitus. Lancet 1976; 2:1213-6.

3 Unger RH, Ipp E, Schusdziarra V, Orci $L$. Hypothesis : physiologic role of pancreatic somatostatin and the contribution of D-cell disorders to diabetes mellitus. Life Sci 1977; 20:2081-6.

4 Sakurai H, Dobbs RE, Unger RH. The effect of somatostatin on the response of GLI to the intraduodenal administration of glucose, protein and fat. Diabetologia 1975; 11:427-30. 
5 Pointner H, Hengl G, Bayer PM, Flegel U. Hemmung des postprandialen Triglyzeridanstiegs im Serum durch Somatostatin beim Menschen. Wien Klin Wochenschr 1977; 89:224-7.

6 Wagner H, Hengst K, Jansen H, Gerlach U. Effects of somatostatin on absorption of mono- and disaccharides in small intestine in vivo and in vitro in man and rats. Metabolism 1978: 27:1329-32.

7 Goldberg DJ, Walesky M, Sherwin RS. Effect of somatostatin on the plasma amino acid response to ingested protein in man. Metabolism 1979; 28: 866-73.

8 Schusdziarra V, Harris V, Arimura A, Unger RH. Evidence for a role of splanchnic somatostatin in the homeostasis of ingested nutrients. Endocrinology 1979; 104:1705-8.

9 Hengl G, Prager J, Pointner H. The influence of somatostatin on the absorption of triglycerides in partially gastrectomized subjects. Acta Hepato-Gastroenterologica 1979; 26:392-5.

10 Pott G, Wagner H, Zierden E et al. Influence of somatostatin on carbohydrate absorption in human small intestine. Klin Wochenschr 1979; 57:131-3.

11 Schusdziarra V, Zyznar E, Rouiller D et al. Splanchnic somatostatin : a hormonal regulator of nutrient homeostasis. Science 1980; 207:530-2.

12 Krejs GJ, Browne R, Raskin P. Effect of intravenous somatostatin on jejunal absorption of glucose, amino acids, water, and electrolytes. Gastroenterology 1980; 78:26-31.

13 Wilson FA, Antonson DL, Hart BL, Warr TA, Cherrington AD, Liljenquist JE. The effect of somatostatin on the intestinal transport of glucose in vivo and in vitro in the rat. Endocrinology 1980; 106:1562-7.

14 Bloom SR, Ralphs DN, Besser GM et al. Effect of somatostatin on motilin levels and gastric emptying. (Abstract). Gut 1975; 16:834 (Abstract).

15 Johansson C, Efendic S, Wisén $\mathrm{O}$, Uvnäs-Wallensten $\mathrm{K}$, Luft R. Effects of short-time somatostatin infusion on the gastric and intestinal propulsion in humans. Scand $J$ Gastroenterol 1977; 13:481-3.

16 Efendic S, Mattson O. Effect of somatostatin on intestinal motility. Acta Radiol. 1978; 19:348-52.

17 Thor P, Krol R, Stanislaw J, Konturek SJ, Coy DH, Schally AV. Effect of somatostatin on myoelectrical activity of small bowel. Am J Physiol 1978; 235:E249E254.

18 Creutzfeldt W, Lankisch PG, Fœlsch UR. Hemmung der sekretin- und - cholezystokinin-pankreozymin-induzierten Saft- und Enzymsekretion des Pankreas und der Gallenblasenkontraktion beim Menschen durch Somatostatin. Dtsch. Med Wochenschr 1975; 100:1135-8.
19 Gomez-Pan A, Reed JD, Albinus M et al. Direct inhibition of gastric acid and pepsin secretion by growth-hormone release inhibiting hormone in cats. Lancet 1975; 1:888-90.

20 Boden G, Sivitz MC Owen OE, Essa-Koumar N, Landor JH. Somatostatin suppresses secretin and pancreatic exocrine secretion. Science 1975; 190:163-4.

21 Wilson RM, Boden G, Shore LS, Essa-Koumar N. Effect of somatostatin on meal-stimulated pancreatic exocrine secretions in dogs. Diabetes $1977 ; 26: 7-10$.

22 Lin TM, Evans DC, Shaar C, Crabtree E. Action of somatostatin on gastric secretion and mucosal blood flow, pancreatic output and release of insulin and growth hormone. (Abstract) Gastroenterology 1976; 70:A101/959.

23 Jaspan J, Polonsky K, Lewis M, Moosa AR. Reduction in portal vein blood flow by somatostatin. Diabetes 1979; 28:888-92.

24 Poulakos L, Kent TH. Gastric emptying and small intestine propulsion in fed and fasted rats. Gastroenterology $1973 ; 64: 962-67$.

25 Salem AA, Cocco AE, Hendrix TR. Inhibition of absorption of d-xylose by phlorizin in the anesthetized rat. $\mathrm{Am} \mathrm{J}$ Physiol 1965; 209:165-8.

26 Michaels EB, Hahn E, Kenyon AJ. An improved procedure for solubilization and assay of blood and feces in liquid scintillation counting. Anal Biochem 1979; 99:288-96.

27 Dahlqvist A. Characterization of intestinal invertase. I. Action on different substrates. Acta Chem. Scand. 1958; 12:2012-19.

28 Long RG, Christofides ND, Fitzpatrick ML, Bloom SR. Contrary effects of exogenous infusion of somatostatin and motilin on glucose tolerance. Diabetologia (Abstract) 1980; 19:295.

29 Marco J, Hedo JA, Villanueva ML. Inhibitory effect of somatostatin on human pancreatic polypeptide secretion. Life Sci 1977; 21:789-92.

30 Sund RB. The effect of dodecylsulphate upon net sodium and water transport from tied jejunal loop in anaesthetized rats. Acta Pharmacol Toxicol 1975; 37:282-96.

31 Lien E, Sarantakis D. Effect of a long acting glucagon selective somatostatin analogue on plasma glucose, insulin and glucagon levels in the anaesthetized rat during arginine infusion. Diabetologia 1979; 17:59-64.

32 Samnegard H, Thulin L, Andreen M, Tyden G, Hallberg D, Efendic S. Circulatory effects of somatostatin in anaesthetized dogs. Acta Chir Scand. 1979; 145:209-12.

33 Bosch J, Kravetz D, Rodes J. Effects of somatostatin on hepatic and systemic hemodynamics in patients with cirrhosis of the liver: comparison with vasopressin. Gastroenterology 1981; 80:518-25. 